\title{
Effect of Picloram on Cinquefoil and
}

\section{Forage Production at the}

\section{Ya-Ha-Tinda Ranch, Alberta}

\section{GEORGE W. SCOTTER}

Highlight: Grass production at the Ya-Ha-Tinda Ranch, Alberta, decreased during the last two decades and shrubby cinquefoil (Potentilla fruticosa L.) and forb production increased, probably as a result of overgrazing by elk and horses. In 1970, plots on three pastures on the ranch were sprayed with $0.5,1.0$, and $1.5 \mathrm{lb} /$ acre of the herbicide, picloram, to determine its effect on shrubby cinquefoil, and on forb and grass production. In 1971, 1972, and 1973, the plots were examined for percent shrub kill, and they were clipped in 1971 and 1972 to determine forb and grass production. Fifty-six to $99 \%$ of all shrubby cinquefoil plants were killed following treatment with different levels of picloram. Total forb production on all three pastures decreased, although sweet-flowered androsace (Androsace chamaejasme Host) and old man's whiskers (Geum triflorum Pursh) showed some resistance to the herbicide. Following the 1970 spraying with picloram, grass production increased by 53\% in 1971 and $77 \%$ in 1972. However, grasses and sedges also increased by $34 \%$ in control plots from 1971 to 1972 because of protection from grazing and favorable precipitation.

Shrubby cinquefoil (Potentilla fruticosa L.) is spreading actively within its natural range in moderately high elevation meadows and grasslands of western Alberta and in the Cypress Hills of southeastern Alberta, although Forest Service (1937) did not consider it to be especially aggressive on rangelands in the western United States. In most instances spreading

The author is research scientist with the Canadian Wildlife Service, Environment Canada, Edmonton, Alberta, Canada.

The author gratefully acknowledges the cooperation of the Agricultural Products Development, Dow Chemical of Canada Limited, for supply and application of the chemical and the staff of the Ya-Ha-Tinda Ranch for construction and maintenance of the exclosures. The field and laboratory assistance of Judy Root and Joe McGillis is acknowledged, also. The project was funded by Parks Canada, Western Region.

Manuscript received April 3, 1974. appears to be associated with poor grazing practices.

Shrubby cinquefoil is generally avoided as forage by all domestic and wild grazing animals in Alberta. In other areas it is reported to be fair to fairly good cattle forage (Forest Service, 1937), occasional to good goat and sheep forage (Forest Service, 1937; Kearney and Peebles, 1951; Elkington and Woodell, 1963), palatable to deer and elk in Montana (Forest Service, 1937), and to deer in Arizona (Kearney and Peebles, 1951).

The normal means of reproduction in shrubby cinquefoil is by seed, although vegetative reproduction by means of prostrate stems which are able to root adventitiously takes place. Seed production is generally high, with about 50 seeds produced per flower and with as many as a few hundred flowers produced on mature shrubs. The main flowering occurs in July on old growth and in August on growth of the current year.

Shrubby cinquefoil has a wide range in North. America: from New England, Labrador and Newfoundland, southwest to the mountains of California, Colorado, and New Mexico, and north to the Arctic slopes of Alaska. The plant has a wide ecological amplitude in Alberta, ranging from the Cypress Hills and foothill prairie regions in the south, in open meadows in the Rocky Mountains, to boggy thickets in the north, and from openings along riverbanks to above the tree line. In most areas the shrub is intolerant of shade.

One possible method of controlling the invasion of grasslands by shrubby cinquefoil is through the use of herbicides. This study was undertaken to see if control of shrubby cinquefoil was possible and to determine the responses of associated plants to the application of herbicide to different levels. There appear to be no published data available on the chemical control of the shrub. Picloram has shown promise for control of many woody plants and herbaceous weeds which infest rangelands (Bovey and Scifres, 1971). 


\section{Study Area and Methods}

The study area was on the Ya-Ha-Tinda Ranch, located in the Red Deer River valley about 3 miles east of the eastern boundary of Banff National Park. About one-third of the 14-square-mile ranch supports rough fescue (Festuca scabrella Torr.) and Junegrass (Koeleria cristata L.) Pers.) grassland, described as a modified stipetosum comatae variant of the Festuco-Stipetum richardsoni association (Looman, 1969). The remainder of the ranch is covered with trees or shrubs.

Less than 20 inches of precipitation may fall each year in valleys between the Continental Divide and the front ranges of the Rockies, and frequent chinooks during winter remove most of the light snowfall. As a result, areas of prairie exist within the mountains, and the Ya-Ha-Tinda Ranch and Kootenay Plains further north in the North Saskatchewan River valley are examples of these (Laycock, 1957).

Horses have grazed the Ya-Ha-Tinda

Table 1. Percent of shrubby cinquefoil plants dead in 1971, 1972, and 1973 following treatment (lb/acre) with picloram in 1970 on the Ya-Ha-Tinda Ranch.

\begin{tabular}{|c|c|c|c|c|c|c|c|c|c|}
\hline \multirow{3}{*}{$\begin{array}{l}\text { Treat- } \\
\text { ment }\end{array}$} & \multicolumn{9}{|c|}{ Percent of shrubs dead } \\
\hline & \multicolumn{3}{|c|}{ Bighorn Creek Pasture } & \multicolumn{3}{|c|}{ Mare's Pasture } & \multicolumn{3}{|c|}{ Scalp Creek Pasture } \\
\hline & 1971 & 1972 & 1973 & 1971 & 1972 & 1973 & 1971 & 1972 & 1973 \\
\hline 0.5 & 79.2 & 72.6 & 64.8 & 61.0 & 55.8 & 66.6 & 74.5 & 63.6 & 60.3 \\
\hline 1.0 & 83.8 & 77.8 & 79.7 & 83.8 & 85.1 & 75.7 & 90.9 & 91.0 & 88.0 \\
\hline 1.5 & 92.3 & 93.8 & 91.6 & 94.6 & 93.0 & 87.0 & 97.7 & 98.9 & 97.1 \\
\hline
\end{tabular}

Ranch for 68 years. In 1905 the Brewster Brothers of Banff applied to the Canadian government for grazing rights on 8,000 acres of land, most of which now comprises the Ya-Ha-Tinda Ranch and from 1905 until 1917 when their lease was terminated, they grazed up to 300 head of saddle and pack horses and some cattle on the ranch.

From 1917 until the present time, Parks Canada used the Ya-Ha-Tinda as a winter grazing area for horses used by the Warden Service during the summer, and to breed horses to maintain the herd. The number of horses has varicd from year to year. In 1929,40 to 60 horses were at the ranch, and from 1926 to 1932 the average number was about 65 (Lothian, 1966). By 1960, 180 to 200 horses grazed at Ya-Ha-Tinda during the winter and 40 to 50 during the summer. Although elk have been present on or near the ranch since it has been used for domestic livestock, their numbers gradually increased and by the winter of 1956-57 ranch foreman $F$. Dixon reported seeing 1,000 head of elk on the ranch at one time.

Although changes in botanical

Table 2. Forage production (lb/acre, air-dried) on Bighorn Creek Pasture sprayed with picloram (lb/acre).

\begin{tabular}{|c|c|c|c|c|c|c|c|c|}
\hline \multirow[b]{3}{*}{ Species } & \multicolumn{8}{|c|}{ Year and treatments } \\
\hline & \multicolumn{4}{|c|}{1971} & \multicolumn{4}{|c|}{1972} \\
\hline & 0 & 0.5 & 1.0 & 1.5 & 0 & 0.5 & 1.0 & 1.5 \\
\hline $\begin{array}{l}\text { Carex sp. } \\
\text { Agropyron spp. }\end{array}$ & 54 & 58 & $\begin{array}{r}73 \\
3\end{array}$ & $\begin{array}{r}72 \\
6\end{array}$ & 56 & $\begin{array}{r}42 \\
128\end{array}$ & $\begin{array}{l}60 \\
91\end{array}$ & $\begin{array}{r}63 \\
143\end{array}$ \\
\hline Bromus pumpellianus & & & & & 5 & & & 5 \\
\hline Elymus innovatus & 60 & 72 & 55 & 78 & 50 & & 57 & \\
\hline Festuca scabrella & 328 & 383 & 587 & 316 & 461 & 663 & 741 & 724 \\
\hline Helictotrichon hookeri & & & & & 14 & 74 & 70 & 84 \\
\hline Koeleria cristata & & & $\operatorname{tr}^{1}$ & 1 & 11 & 2 & 27 & 9 \\
\hline Muhlenbergia richardonis & 10 & & & & & 6 & & \\
\hline $\begin{array}{l}\text { Poa interior } \\
\text { Trisetum spicatum }\end{array}$ & 16 & 51 & 70 & 51 & $\begin{array}{l}12 \\
22\end{array}$ & 14 & $\begin{array}{r}8 \\
13\end{array}$ & $\begin{array}{l}26 \\
26\end{array}$ \\
\hline Unidentified grasses & & 2 & 28 & & & 3 & 40 & \\
\hline Total grasses and grasslike plants & 468 & $566 *$ & $816^{* *}$ & 524 & 631 & $932 * *$ & $1107^{* *}$ & $1080 * *$ \\
\hline Achillea millefolium var. nigrescens & 6 & & & & & & & \\
\hline Agoseris glauca & 17 & & & & & & & \\
\hline Androsace chamaejasme & 28 & 17 & 12 & 9 & 4 & 14 & 14 & 73 \\
\hline Anemone multifida var. hudsoniana & & & 1 & & 7 & & & \\
\hline Antennaria parviflora & 151 & & & & 66 & & & \\
\hline Artemisia frigida & & & & & 2 & & & \\
\hline Aster alpinus & 15 & & & & & & & \\
\hline Cerastium arvense & 15 & & & & 19 & & & \\
\hline Cruciferae sp. & 7 & & & & & & & \\
\hline Erigeron caespitosus & & & & & 67 & & & \\
\hline Geum triflorum & 95 & 14 & 7 & & 243 & 8 & 24 & \\
\hline Hedysarum alpinum var. americanum & 1 & & & & & & & \\
\hline Hieracium sp. & & & & & 10 & & & \\
\hline Linum lewisii & & & & & 3 & & & \\
\hline Oxytropis campestris var. gracilis and & & & & & & & & \\
\hline O. splendens & 116 & & & & 91 & & & \\
\hline Potentilla nivea and $P$. pensylvanica & 3 & & & & 32 & 8 & & \\
\hline Solidago spathulata & 17 & & & & & & & \\
\hline Unidentified forbs & & & & & 2 & & & 1 \\
\hline Total forbs & 471 & $31 * *$ & $20 * *$ & $9 * *$ & 546 & $30 * *$ & $38 * *$ & $74 * *$ \\
\hline Total herbage & 939 & 597 & 836 & 533 & 1177 & 962 & 1145 & 1154 \\
\hline
\end{tabular}

* Production significantly different from production in unsprayed areas at the $5 \%$ level of probability.

**Production significantly different from production in unsprayed areas at the $1 \%$ level of probability.

$1 \mathrm{tr}=$ less than $0.5 \mathrm{lb} / \mathrm{acre}$. 
composition are not well documented, it appears that shrubby cinquefoil and various forbs have rapidly increased in numbers on the range, probably as a result of overgrazing in the spring, and that grass and grass-like plants have decreased. Flook (1957) wrote: "The grassland ... is generally in good condition. The current utilization of the grass is heavy. I believe that if it continues at the present rate, the range will deteriorate rapidly. In some sections large numbers of seedlings of shrubby cinquefoil about 4 years old are present."

In 1970, three areas in which shrubby cinquefoil bushes were numerous were fenced: Bighorn Creek, Mare's, and Scalp Creek pastures, respectively. Site potential for forage production is low at Scalp Creek, high at Mare's pasture, and intermediate at Bighorn Creek. The Scalp Creek and Bighorn Creek sites are alluvial fans with thin soil mantles and rocky subsoils which allow for rapid percolation of soil moisture. Of those two sites, the one at Scalp Creek has the greater rock content. Soil at the Mare's pasture site is a deep loam. All three sites were on level ground with the Mare's pasture site about $100 \mathrm{ft}$ higher in elevation than the other two.

Within each exclosure four 1- by 4-rod plots were established and sprayed with a herbicide, the active ingredient of which is picloram (4-amino-3,5,6-trichloropicolinic acid). Plots were separated by a width of one rod to prevent contamination of adjacent plots by wind-drifted herbicide. In each exclosure one plot was sprayed with $0.5 \mathrm{lb} / \mathrm{acre}$, one with $1.0 \mathrm{lb} / \mathrm{acre}$, and one with $1.5 \mathrm{lb} / \mathrm{acre}$, and the fourth plot was left unsprayed as a control. Plots were sprayed on July 29, with good soil moisture conditions and an air temperature of approximately $65^{\circ} \mathrm{F}$. Several forbs and shrubby cinquefoil were at the peak of their flowering stage at the time of application.

The number of dead and living shrubby cinquefoil in each plot was counted in 1971,1972 , and 1973. Ten microplots, each $0.96 \mathrm{ft}^{2}$, were spaced randomly along the long axis of each plot. Herbaceous plants from microplots were clipped, air dried, identified and weighed, and the total yield of grasses and forbs was calculated for each pasture in 1971 and 1972 .

\section{Results}

\section{Effect on Shrubby Cinquefoil}

At all three pastures, higher concentrations of picloram resulted in higher percentages of dead shrubby cinquefoil plants (Table 1). An average of $66 \%$ of the plants were killed during the 3 years on pastures sprayed with
$0.5 \mathrm{lb} /$ acre of picloram, an average of $84 \%$ were killed with $1.0 \mathrm{lb} / \mathrm{acre}$, and $94 \%$ were killed with $1.5 \mathrm{lb} /$ acre.

\section{Effect on Forb Production}

In general, forb production on the three pastures decreased following treatment with picloram, although a few species, including sweet-flowered androsace (Androsace chamaejasme Host) and old man's whiskers (Geum triflorum Pursh), were relatively resistant to the herbicide (Tables 2, 3, and 4).

\section{Bighorn Creek Pasture}

In 1971 total forb production on Bighorn Creek Pasture decreased with increasing concentrations of picloram: unsprayed, $471 \mathrm{lb} /$ acre of forbs; 0.5 lb/acre, 31 lb/acre of forbs; 1.0 $\mathrm{lb} /$ acre, $20 \mathrm{lb} /$ acre of forbs; and 1.5 lb/acre, $9 \mathrm{lb} /$ acre of forbs (Table 2). From 1971 to 1972 there was a $16 \%$ increase in total forb production in the control plot, but production in the treated plots remained comparatively low: unsprayed, $546 \mathrm{lb} /$ acre of forbs; $0.5 \mathrm{lb} /$ acre, $30 \mathrm{lb} /$ acre of forbs; 1.0 $\mathrm{lb} /$ acre, $38 \mathrm{lb} /$ acre of forbs; 1.5 $\mathrm{lb} / \mathrm{acre}, 74 \mathrm{lb} / \mathrm{acre}$ of forbs. Two forbs, sweet-flowered androsace and old man's whiskers, exhibited some

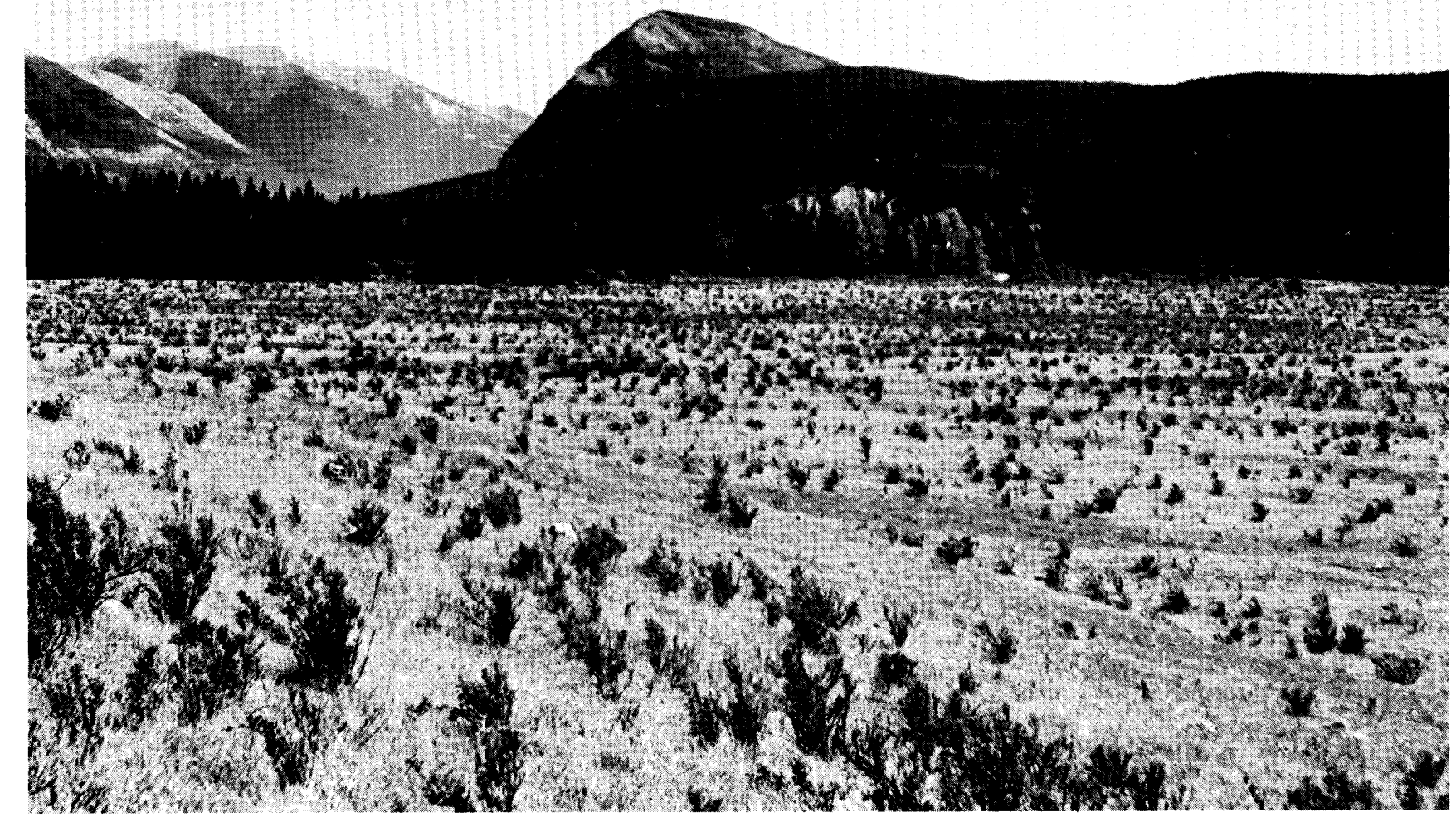

Fig. 1. Shrubby cinquefoil in rough fescue grassland of the Mare's Pasture, Ya-Ha-Tinda Ranch, prior to spraying. (Photo by R. E. Stevenson.) 
resistance to picloram and these species account for most of the forb production in the treated plots. In 1971 there was a decrease in the production of sweet-flowered androsace in all treated plots compared with the control: unsprayed, $28 \mathrm{lb} /$ acre; $0.5 \mathrm{lb} /$ acre, 17 $\mathrm{lb} / \mathrm{acre} ; 1.0 \mathrm{lb} / \mathrm{acre}, 12 \mathrm{lb} / \mathrm{acre} ; 1.5$ lb/acre, $9 \mathrm{lb} /$ acre. However in 1972 this species increased in production compared with the control, especially in the plot sprayed with $1.5 \mathrm{lb} /$ acre of picloram: unsprayed, $4 \mathrm{lb} /$ acre; 0.5 lb/acre, $14 \mathrm{lb} / \mathrm{acre} ; 1.0 \mathrm{lb} / \mathrm{acre}, 14$ lb/acre; $1.5 \mathrm{lb} /$ acre, $73 \mathrm{lb} /$ acre. In both 1971 and 1972 old man's whiskers, the less resistant of the two species, amounted to less than $25 \mathrm{lb} /$ acre on plots sprayed with 0.5 and $1.0 \mathrm{lb} / \mathrm{acre}$ of herbicide, compared with $95 \mathrm{lb} /$ acre and $243 \mathrm{lb} / \mathrm{acre}$ in the control plot. It was completely eliminated by the treatment with $1.5 \mathrm{lb} / \mathrm{acre}$ of picloram.

\section{Mare's Pasture}

Almost all of the forb species on the Mare's Pasture were completely eliminated after treatment with picloram, the main exception again being sweet-flowered androsace (Table 3). Between 56 and $70 \mathrm{lb} /$ acrc of sweet-flowered androsace were found on treated plots, compared with 114 lb/acre on the control plot in 1971 and $99 \mathrm{lb} /$ acre in 1972. Total forb production decreased from $930 \mathrm{lb} /$ acre in the control plot in 1971 to 79,70 , and $71 \mathrm{lb} /$ acre in the treated plots, and from $592 \mathrm{lb} /$ acre in the control plot in 1972 to 82,64 , and $61 \mathrm{lb} /$ acre in the treated plots. There was a decrease in total forb production in the control arca from 1971 to 1972 .

\section{Scalp Creek Pasture}

As on Bighorn Creek Pasture and
Mare's Pasture nearly all of the forb species on Scalp Creek Pasture were completely eliminated following treatment with picloram, the main exceptions being sweet-flowered androsace, old man's whiskers, and saxifrage (Saxifraga sp.) (Table 4). Total forb production decreased from $548 \mathrm{lb} /$ acre in the control plot in 1971 to 26,46 , and $18 \mathrm{lb} /$ acre in the treated plots, and from $179 \mathrm{lb} /$ acre in the control plot in 1972 to 36,61 , and 12 lb/acre in the treated plots. Sweet-flowcred androsace was most abundant in 1971 and 1972 in the plot sprayed with $1.0 \mathrm{lb} / \mathrm{acre}$ of the herbicide (46 and $42 \mathrm{lb} /$ acre compared with 25 and $23 \mathrm{lb} /$ acre in the control plot). Old man's whiskers was only present in the control plots in 1971 and 1972 (137 lb/acre and $25 \mathrm{lb} /$ acre respectively) and in the plot sprayed with $0.5 \mathrm{lb} /$ acre $(26 \mathrm{lb} /$ acre and 34 lb/acre in 1971 and 1972

Table 3. Forage production (lb/acre, air-dried) on the Mare's Pasture sprayed with picloram (lb/acre).

\begin{tabular}{|c|c|c|c|c|c|c|c|c|}
\hline \multirow[b]{3}{*}{ Species } & \multicolumn{8}{|c|}{ Year and treatments } \\
\hline & \multicolumn{4}{|c|}{1971} & \multicolumn{4}{|c|}{1972} \\
\hline & 0 & 0.5 & 1.0 & $\overline{1.5}$ & 0 & 0.5 & 1.0 & 1.5 \\
\hline Carex sp. & 74 & 82 & 115 & 137 & 58 & 68 & 65 & 92 \\
\hline Juncus sp. & 1 & 54 & 17 & & 3 & 54 & 10 & \\
\hline Agropyron spp. & 7 & 3 & 10 & & 22 & 1 & 10 & 51 \\
\hline Elymus innovatus & 152 & 211 & 157 & 66 & 165 & 242 & 183 & 94 \\
\hline Festuca scabrella & 383 & 634 & 547 & 892 & 582 & 1058 & 1040 & 1218 \\
\hline Helictotrichon hookeri & 1 & & & & 3 & 56 & 11 & 92 \\
\hline Koeleria cristata & 3 & & & & & 9 & 11 & 11 \\
\hline Poa interior & 73 & 71 & 103 & 140 & 61 & 65 & 143 & 146 \\
\hline Trisetum spicatum & & & & & & 13 & & \\
\hline Unidentified grasses & 25 & 41 & 16 & & 35 & 61 & 19 & \\
\hline Total grasses and grasslike plants & 719 & $1096^{*}$ & $965 *$ & $1235 * *$ & 929 & $1627 * *$ & $1492 * *$ & $1704 * *$ \\
\hline Achillea millefolium var. nigrescens & 25 & & & & 6 & & & \\
\hline Agoseris glauca & 19 & & & & 8 & & & \\
\hline Androsace chama ejasme & 114 & 56 & 70 & 63 & 99 & 69 & 64 & 61 \\
\hline Anemone multifida var. hudsoniana & 11 & 7 & $\mathrm{tr}$ & & 45 & & & \\
\hline Antennaria parviflora & 2 & & & & & & & \\
\hline Arnica sp. & & 1 & & & & & & \\
\hline Artemisia frigida & 26 & 1 & & & 2 & & & \\
\hline Aster alpinus & 19 & & & & & & & \\
\hline Cerastium arvense & 34 & & & & 25 & & & \\
\hline Cruciferae sp. & 11 & & & & & & & \\
\hline Delphinium brownii & & & & & 24 & & & \\
\hline Erigeron caespitosus & 13 & & & 2 & & & & \\
\hline Gallium boreale & 19 & & & & 11 & & & \\
\hline Geum triflorum & 116 & 2 & & 6 & 115 & 12 & & \\
\hline Hedysarum alpinum var. americanum & 88 & & & & 23 & & & \\
\hline Hieracium sp. & & & & & 4 & & & \\
\hline Linum lewisii & & & & & 6 & & & \\
\hline Oxytropis campestris var. gracilis and $O$. splendens & 378 & & & & 143 & & & \\
\hline Potentilla nivea and $P$. pensylvanica & 4 & & & & & & & \\
\hline Thalictrum sp. & 20 & 11 & & & 19 & 1 & & \\
\hline Unidentified forbs & 31 & 1 & & & 62 & & $\operatorname{tr}^{1}$ & \\
\hline Total forbs & 930 & $79 * *$ & $70 * *$ & $71 * *$ & 592 & $82 * *$ & $64 * *$ & $61 * *$ \\
\hline Total herbage & 1649 & 1175 & 1035 & 1306 & 1521 & 1709 & 1556 & 1765 \\
\hline
\end{tabular}

* Production significantly different from production in unsprayed areas at the $5 \%$ level of probability.

$* *$ Production significantly different from production in unsprayed areas at the $1 \%$ level of probability.

$1 \mathrm{tr}=$ less than $0.5 \mathrm{lb} / \mathrm{acre}$. 
respectively).

Effect on Grass and Grass-like Plant Production

Grass production increased following spraying with picloram on all three pastures tested.

\section{Bighorn Creek Pasture}

The total production of grasses and sedges on Bighorn Creek Pasture in 1971 increased from $468 \mathrm{lb} /$ acre in the control area to 566,816 , and 524 $\mathrm{lb} / \mathrm{acre}$ on plots sprayed with $0.5,1.0$, and $1.5 \mathrm{lb} /$ acre of picloram. In 1972 production increased from $631 \mathrm{lb} /$ acre in the control area to 932,1107 , and $1080 \mathrm{lb} /$ acre on plots sprayed with $0.5,1.0$, and $1.5 \mathrm{lb} / \mathrm{acre}$ of picloram (Table 2). Grass and sedge production on plots sprayed with the herbicide thus increased above the control by an average of $36 \%$ in 1971 and $65 \%$ in 1972. However, not all increase was due to the effect of the herbicide since the spring and early summer of 1972 were wet and production on the unsprayed plots increased by 35\% above the 1971 level. The plots were also protected from grazing by livestock.

The dominant grass, rough fescue, increased from 1971 to 1972 : 328 to $461 \mathrm{lb} /$ acre in the control plot; 383 to $663 \mathrm{lb} /$ acre in the plot sprayed with $0.5 \mathrm{lb} / \mathrm{acre}$ of picloram; 587 to 741 $\mathrm{lb} /$ acre in the plots sprayed with 1.0 $\mathrm{lb} / \mathrm{acre}$; and 316 to $724 \mathrm{lb} / \mathrm{acre}$ in the plot sprayed with $1.5 \mathrm{lb} /$ acre (Table 2).

Wheatgrasses showed a pronounced foliar injury from the spray soon after the treatment. Foliage showed a drooping growth habit with twisted stems and rolled leaf blades. The symptoms were present only during the summer of the spray application.

\section{Mare's Creek Pasture}

Total grass and grass-like plant production in 1971 on Mare's Creek Pasture increased from $719 \mathrm{lb} / \mathrm{acre}$ in the control plot to 1096,965 , and $1235 \mathrm{lb} /$ acre in the plots sprayed with
$0.5,1.0$, and $1.5 \mathrm{lb} /$ acre of picloram (Table 3). Grass and grass-like plant production in the treated plots in 1972 ranged between 1492 and 1704 lb/acre compared with $929 \mathrm{lb} /$ acre in the control plot. In all treated plots production of grasses and grass-like plants in 1972 was greater than in 1971. There was a $48 \%$ increase in production in the plot sprayed with $0.5 \mathrm{lb} /$ acre of picloram, a $55 \%$ increase with $1.0 \mathrm{lb} / \mathrm{acre}$, and an increase of $38 \%$ with $1.5 \mathrm{lb} /$ acre. However, production in the control plot increased by 29\% from 1971 to 1972.

Individual grass species showed varied responses to the herbicide. Rough fescue, increased from 1971 to 1972: 383 to $582 \mathrm{lb} /$ acre in the control plot; 634 to $1058 \mathrm{lb} /$ acre in the plot sprayed with $0.5 \mathrm{lb} / \mathrm{acre}$ of picloram; 547 to $1040 \mathrm{lb} /$ acre in the plots sprayed with $1.0 \mathrm{lb} / \mathrm{acre}$; and 892 to $1218 \mathrm{lb} / \mathrm{acre}$ in the plot sprayed with $1.5 \mathrm{lb} /$ acre (Table 3 ). In 1971 and 1972 hairy wildrye (Elymus innovatus Beal) production was 211

Table 4. Forage production (lb/acre, air-dried) on Scalp Creek Pasture sprayed with picloram (lb/acre).

\begin{tabular}{|c|c|c|c|c|c|c|c|c|}
\hline \multirow[b]{3}{*}{ Species } & \multicolumn{8}{|c|}{ Year and treatment } \\
\hline & \multicolumn{4}{|c|}{1971} & \multicolumn{4}{|c|}{1972} \\
\hline & 0 & 0.5 & 1.0 & 1.5 & 0 & 0.5 & 1.0 & 1.5 \\
\hline Carex sp. & 39 & 31 & 72 & 31 & 21 & 8 & 5 & 9 \\
\hline Agropyron spp. & & 31 & & 4 & 111 & 60 & 110 & 121 \\
\hline Elymus innovatus & 26 & 15 & 64 & 25 & 19 & & 4 & \\
\hline Festuca scabrella & 104 & 152 & 223 & 246 & 126 & 415 & $411^{\circ}$ & 483 \\
\hline Helictotrichon hookeri & & 1 & & & & 1 & 47 & \\
\hline Koeleria cristata & 1 & & 18 & & & 70 & 41 & 16 \\
\hline Muhlenbergia richardsonis & & 4 & & & 2 & & 1 & \\
\hline Poa interior & 7 & 43 & 132 & 63 & 2 & 54 & 51 & 45 \\
\hline Unidentified grasses & 29 & 26 & & 15 & 31 & 35 & & 24 \\
\hline Total grasses and grasslike plants & 206 & 303 & $509 * *$ & $384 * *$ & 310 & $643 * *$ & $670 * *$ & $698 * *$ \\
\hline Achillea millefolium var. nigrescens & 18 & & & & 5 & & & \\
\hline Androsace chamaejasme & 25 & & 46 & 18 & 23 & 2 & 42 & 12 \\
\hline Anemone multifida var. hudsoniana & & & & & 1 & & 1 & \\
\hline Antennaria parviflora & 92 & & & & 37 & & & \\
\hline Artemisia frigida & 7 & & & & $\operatorname{tr}^{1}$ & & & \\
\hline Campanula rotundifolia & & & & & 16 & & & \\
\hline Cerastium arvense & 12 & & & & 15 & & & \\
\hline Cruciferae sp. & 8 & & & & 1 & & & \\
\hline Draba sp. & 5 & & & & & & & \\
\hline Geum triflorum & 137 & 26 & & & 25 & 34 & & \\
\hline Hedysarum alpinum var. americanum & & & & & 10 & & & \\
\hline Oxytropis campestris var. gracilis and $O$. splendens & 191 & & & & 41 & & & \\
\hline Saxifraga sp. & & & & & & & 17 & \\
\hline Senecio sp. & 47 & & & & & & & \\
\hline & 4 & & & & 3 & & 1 & \\
\hline Solidago spathulata & & & & & & & & \\
\hline Unidentified forbs & 2 & & & & 5 & & & \\
\hline Total forbs & 548 & $26 * *$ & $46^{* *}$ & $18 * *$ & 179 & $36 * *$ & $61 * *$ & $12 * *$ \\
\hline Total herbage & 754 & 329 & 555 & 402 & 489 & 679 & 731 & 710 \\
\hline
\end{tabular}

\footnotetext{
* Production significantly different from production in unsprayed areas at the $5 \%$ level of probability.
}

* *Production significantly different from production in unsprayed areas at the $1 \%$ level of probability.

$1 \mathrm{tr}=$ less than $0.5 \mathrm{lb} / \mathrm{acre}$. 
and $242 \mathrm{lb} /$ acre after spraying with 0.5 $\mathrm{lb} / \mathrm{acre}$ picloram, compared with 152 and $165 \mathrm{lb} / \mathrm{acre}$ in the control plot. However, higher concentrations of the herbicide caused production decreases to 157 and $183 \mathrm{lb} /$ acre (with 1.0 $\mathrm{lb} / \mathrm{acre}$ picloram and 66 and $94 \mathrm{lb} / \mathrm{acre}$ with $1.5 \mathrm{lb} / \mathrm{acre}$ picloram) when compared with $0.5 \mathrm{lb} / \mathrm{acre}$. Bluegrass (Póa interior Rydb.) gencrally increased with higher concentrations of picloram in both 1971 and 1972 from 73 to $61 \mathrm{lb} /$ acre on the control plot to between 103 and $146 \mathrm{lb} /$ acre in the 1.0 and $1.5 \mathrm{lb} /$ acre treated plots.

\section{Scalp Creek Pasture}

The total production of grasses and sedges on Scalp Creek Pasture in 1971 increased from $206 \mathrm{lb} / \mathrm{acre}$ in the control area to 303,509 , and 384 $\mathrm{lb} /$ acre on plots sprayed with $0.5,1.0$, and $1.5 \mathrm{lb} /$ acre of picloram, and in 1972 increased from $310 \mathrm{lb} /$ acre in the control area to 643,670 , and 698 $\mathrm{lb} / \mathrm{acre}$ on the three treatments, respectively (Table 4). Grass and sedge production increased above the control by an average of $93 \%$ in 1971 and $116 \%$ in 1972 on plots sprayed with the herbicide. Production also increased by an average of $68 \%$ on the sprayed plots and $50 \%$ on unsprayed plots from 1971 to 1972.

Again rough fescue increased from $104 \mathrm{lb} /$ acre in the control to 152,223 , and $246 \mathrm{lb} /$ acre in the treated plots in 1971 , and from $126 \mathrm{lb} / \mathrm{acre}$ in the control to 415,411 , and $483 \mathrm{lb} / \mathrm{acre}$ in 1972 (Table 4).

\section{Discussion}

In other studies (Bovey and Scifres, 1971; Peters and Lowrance, 1969; Robocker, 1971; Tueller and Evans, 1969) the effective rates for rangeland renovation using picloram vary from 0.25 to $2 \mathrm{lb} / \mathrm{acre}$. These rates usually were not reported to damagc established grasses. The reaction of desirable grass species in rangeland ecosystems to picloram, however, received only little attention. Differential susceptibility of grass species to picloram has been noted in a few cases. For example, some production loss in smooth brome (Bromus inermis Leyss.), quackgrass (Agropyron repens (L.) Beauv.), foxtail barley (Hordeum jubatum L.), and cottontop (Digitaria californica (Benth.) Henr.) treated with picloram has been reported (McCarty and Scifres, 1968; Scifres and Halifax, 1972a; Vanden Born, 1965; Warden, 1964).

In the present study picloram visibly reduced the number of seed heads of wheatgrasses (Agropyron spp.). No visible differences in seed head numbers for other grass species were detected. Picloram, while not reducing viability, was reported to adversely affect seed production of some grass species (Lee, 1970). It is also known to reduce root elongation and production and to reduce seedling establishment in some grass species (Chang and Foy, 1971; McCarty and Scifres, 1968; Scifres and Halifax, 1972a, 1972b).

The time of application to rangelands may be critical. Arnold and Santelmann (1966) found that preemergence applications killed all seedlings of four range grass species and that applications at the two-leaf stage reduced survival.

Picloram has shown more toxicity to many broadleaf plants than 2,4-D and 2,4,5-T. In the present study, forb yields were significantly reduced by all rates of herbicide treatment. Arnold and Santelmann (1966) also reported that the application of picloram to established native range gave good control of several broadleaved forbs. Toxic residucs of picloram, at the rates applied, may remain in the soil for periods of 1 to 2 years (Goring et al., 1965; Herr et al., 1966).

\section{Summary and Conclusions}

The application of picloram improved the forage in the experimental plots at the Ya-Ha-Tinda Ranch by reducing the number of shrubby cinquefoil bushes, decreasing forb production and increasing grass and grass-like plant production. Fifty-six to $99 \%$ of shrubby cinquefoil plants were killed following treatment with picloram.

Grass and grass-like plant production in treated plots increased an average of $53 \%$ in 1971, an average of $77 \%$ in 1972, and an average of $55 \%$ from 1971 to 1972 after spraying with picloram. However, some of this increase in production was due to high precipitation in the spring and early summer of 1972, and to protection from grazing provided by the fences surrounding the treated areas. Most forb species were completely eliminated after treatment wi picloram, with the exception sweet-flowered androsace and $c$ man's whiskers, which appcared to somewhat resistant to the herbicide.

The $1.0 \mathrm{lb} /$ acre concentration picloram appears to be economica the most effective for improvi forage production on ranges infest with shrubby cinquefoil. The high shrub kill on all three pastures $x$ obtained with the $1.5 \mathrm{lb} / \mathrm{ar}$ concentrations of picloram, but exceeded the $1.0 \mathrm{lb} /$ acre treatment only $10 \%$. Forb production was low all treatment levels and grass a grasslike plant production werc fai similar at all three levels following $t$ second year after treatment.

Shrubby cinquefoil, in the prese study, was effectively controlled picloram at the two high concentrations. Control at $0.5 \mathrm{lb} / \mathrm{ar}$ was not considered to be satisfacto

\section{Literature Cited}

Arnold, W. R., and P. W. Santelmann. 19 The response of native grasses and fo to picloram. Weeds 14:74-76.

Bovey, R. W., and C. J. Scifres. 19 Residual characteristics of picloram grassland ecosystems. Texas Agr. E: Sta. Bull. 1111. 24 p.

Chang, I., and C. L. Foy. 1971. Effect picloram on germination and scedl development of four species. Weed : 19:58-64.

Elkington, T. T., and S. R. J. Wood 1963. Potentilla fruticosa L. J. Ecol 51:769-781.

Flook, D. 1957. Elk-horse grazing situati Ya Ha Tinda Ranch, 1957. Unpu Canad. Wildl. Serv., Edmonton, Albe

Forest Service, 1937. Range pl handbook. U.S. Dep. Agr., Wash., D

Goring, C. A. I., C. R. Youngson, and J. Hamaker. 1965. Tordon herbicide Disappearance from soils. Down to Ea 20(4):3-5.

Herr, E., E. W. Stroube, and D. A. R 1966. Effect of Tordon residues agronomic crop. Down to Ea 21(4):17-18.

Kearney, T. H., and R. H. Peebles. 19 Arizona flora. University of Califor Press.

Laycock, A. H. 1957. A physiograp classification of soils for land planning on the eastern slopes of Canadian Rockies. PhD thesis, Univ. Minnesota.

Lee, W. O. 1970. Effect of picloram production and quality of seed in seve grasses. Weed Sci. 18:171-173.

Looman, J. 1969. The Fescue grasslands western Canada. Vegetatio 19:128-1

Lothian, W. F. 1966. A brief history of $\mathrm{Ha}$ Tinda Ranch. Unpubl. rep National and Historic Parks Branch fi Ottawa. 


\section{McCarty, M. K., and C. J. Scifres. 1968.} Smooth bromegrass response to herbicides as affected by time of application in relation to nitrogen fertilization. Weed Sci. 16:443-446.

Peters, E. J., and S. A. Lowrance. 1969. Gains in timothy forage goldenrod control with 2,4-D 2,4-DB and picloram. Weed Sci. 17:473-474.

Robocker, W. C. 1971. Herbicidal suppression of bracken and effects on forage production. Weed Sci. 19:538-541.

Scifres, C. J., and J. C. Halifax. 1972a. Development of range grass seedlings germinated in picloram. Weed Sci. 20:341-344.

Scifres, C. J., and J. C. Halifax. 1972b. Root production of seedling grasses in soil containing picloram. J. Range Manage. 25:44-46.

Tueller, P. T., and R. A. Evans. 1969.
Control of green rabbitbrush and big sagebrush with 2,4-D and picloram. Weed Sci. 17:233-235.

Vanden Born, W. H. 1965. The effect of dicamba and picloram on quackgrass, bromegrass and Kentucky bluegrass. Weeds 13:309-312.

Warden, R. L. 1964. Tordon ... for the control of field bindweed and Canada thistle in the North Central United States. Down to Earth 20(2):6-10. 